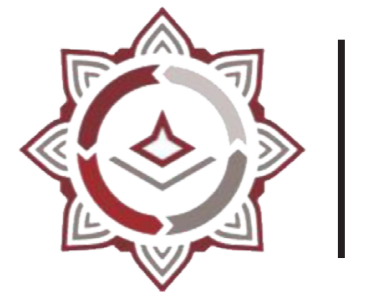

BISNIS: Jurnal Bisnis dan Manajemen Islam

P-ISSN: 2442-3718, E-ISSN: 2477-5533

Volume 9, Nomor 1, Juni 2021 (PP : 107-126)

https://journal.iainkudus.ac.id/index.php/Bisnis/index

http://dx.doi.org/10.21043/bisnis.v9i1.11422

\title{
Strategi Membangun Kewirausahaan Santri Menggunakan Model Pendidikan Taxonomi Bloom
}

\author{
M. Mun'im¹, Pardiman $^{2}$, Supriyanto ${ }^{3}$ \\ Universitas Islam Malang, Indonesia ${ }^{123}$ \\ Muhammadmunim60@gmail.com ${ }^{1}$,pardiman@unisma.ac.id², maspriyanto79@gmail.com³
}

\begin{abstract}
Pesantren is one of the many educational institutions in Indonesia which teaches Islamic religious knowledge to its students. Besides being equipped with religious knowledge, students are also believed to be able to face the challenges of the times, even students can also create jobs and become successful santripreneurs, by being given entrepreneurial education to students. This study aims to analyze how educational strategies are given to students and their implications. This research method uses qualitative research with a descriptive approach with a multi-site design. The data collection method in this research is using interviews, observation and documentation by checking the validity of the data using the triangulation method. This study uses qualitative descriptive data analysis techniques by reducing data, presenting verification data and drawing conclusions. students are given knowledge and understanding of entrepreneurship. 2) students are given affective entrepreneurship education in which there is provision of training, motivation and entrepreneurial values. 3) In addition to being provided with cognitive and affective education, students are also provided with psychomotor education to form students' mental and skills by direct practice in the field with various entrepreneurial activities such as selling goods and services.
\end{abstract}

Keywords: Strategic Management, Entrepreneurship Education, Santri, Islamic Boarding School

\begin{abstract}
Abstrak:
Pesantren ialah diantara dari sekian satu banyak dari lembaga pendidikan yang berada di Indonesia yang di dalamnya mentransfer ilmu agama Islam pada santri-santrinya. selain dibekali ilmu agama santri juga dipercaya mampu menghadapi tantangan zaman, bahkan santri juga bisa untuk membuka lapangan pekerjaan serta menjadi santripreneur yang
\end{abstract}

BISNIS, Vol. 9, №. I Juni ZQZI 
sukses, dengan diberikan pendidikan kewirausahaan kepada santri. Penelitian ini bertujuan untuk menganalisis bagaimana strategi pendidikan yang diberikan kepada santri beserta implikasinya. Metode penelitian memakai riset kualitatif dengan pendekatan deskriptif serta rancangan multisitus. Metode pengumpulan datanya dalam penelitian ini yaitu menggunakan pewawancaraan, pengobservasani serta pendokumentasian dengan pengecekan keabsahan data yang menggunakan metode triangulasi. Penelitian ini memakai teknik analisis data deskriptif kualitatif dengan mereduksi data, penyajian data verifikasi dan penarikan simpulan. Dari hasil penelitian bersimpulan bahwa dalam membangun entrepreneurship santri di Pondok Pesantren Al-Mawaddah Kudus serta Pesantren Raudlatun Nasyiin Rembang yaitu 1) memberikan pendidikan kewirausahaan secara kognitif yang didalamnya santri diberi pengetahuan dan pemahaman mengenai ilmu kewirausahaan. 2) santri diberikan pendidikan kewirausahaan secara afektif yang didalamnya terdapat pemberian pelatihan, motivasi dan nilai-nilai kewirausahaan. 3) selain dibekali pendidikan kognitif dan afektif santri juga dibekali pendidikan psikomotorik untuk membentuk mental dan keterampilan santri dengan cara praktik langsung dilapangan dengan berbagai kegiatan kewirausahaan seperti menjual barang dan jasa.

Kata kunci: Manajemen Strategi, Pendidikan Kewirausahaan, Santri, Pondok Pesantren

\section{PENDAHULUAN}

Pondok pesantren memiliki peran yang besar dalam upaya mencerdaskan kehidupan bangsa. Dimulai sejak pra kemerdekaan sampai sekarang, di samping itu pesantren telah berperan sebagai agen pembahatuan sosial seperti transmigrasi, keluarga berencana dan gerakan akan sadar lingkungan (Andriyani, Hasan et al., 2018). Selanjutnya santri dapat juga dimengerti bahwa bersosok individualis yang sangat ideal dalam mencapai tujuan dalam membangun usaha-usaha perbaikan bangsa serta agama. Hal ini dapat dilihat dari peningkatan santri yang setiap tahun meningkat yang sangat signifikan dengan jumlah pondok pesantren yang ada di Indonesia sebesar 26.978 pada tahun 2020. (Takdir, 2018)

Pada era sekarang ini tidak sedikit pesantren yang meningkatkan semangat entrepreneurship dengan berharap bisa melaksanakan pentransformasian sosial. Keberadaan pesantren selaku agen pengembangan warga, sangat diharapkan mempersiapkan beberapa konsep pengembangan sumber manusia, baik buat kenaikan mutu pondok pesantren ataupun kenaikan mutu kehidupan warga. Di masa globalisasian ini lah harus pandai-pandai dalam meraih hasil yang maksimal agar tidak tertinggal, pesantren wajib dibangun sumber energi manusia, tidak lumayan dengan mem- bangun satu aspek kejiwaan spiritualisme saja tapi juga dibutuhkan 
pula bermacam pengetahuan serta ketrampilan (skill) yang sepanjang ini masih menjadi kekurangan yang dipadati di pondok pesantren. (Kahfi, 2016)

Kemudian bagian yang paling utama dalam kasus ini ialah menerjemahkan kegiatan berwirausaha atau kegiatan ekonomi dalam pelatihan atau reduksi. Macammacam cara untuk meningkatan mutu untuk santri dalam pengingkatanya ialah dari skillnya, keterampilannya, serta wawasannya. Karena perlu diketahui bahwa cita-cita seorang santri tidak semuanya lantas menjadi kyai atau ustadz, tidak sedikit juga yang lebih suka dengan keterampilanya ini kewirausahaan serta berbisnis. Untuk pengembangan sistem pendidikan, pesantren hendaknya memiliki networking yang kuat dengan berbagai lembaga di bidang yang memiliki kesamaan visi. Dalam MEA, pesantren diharapkan memiliki jejaring yang mutualisme dengan berbagai institusi pendidikan dan industri, sebagai usaha menyerap kebutuhan pembelajaran dan kompetensi lulusan agar pengembangan pendidikan bisa efektif dan efisien. (Yasid and Pesantren, 2018)

Pendidikan pesantren berwawasan harus memiliki visi dan misi yang secara subtansial memiliki target tercapainya pendidikan yang menjungjung tinggi kemerdekaan, keterampilan, kreativitas, inovasi dan kompetisi. Bermacam riset sempat dicoba buat memandang gimana kedudukan pesantren dalam pembangunan warga. Salah satu riset yang sempat dicoba oleh (Afidah, 2018) menampilkan kalau pemikiran santri di pesantren tentang entrepreneur merupakan selaku keahlian buat merintis usaha mandiri untuk bersumbahsih pada suatu tumbuhnya perekonomian secara mandiri. Selain itu, (Hayana and Wahidmurni, 2019) dalam penelitiannya menyimpulkan kalau penstrategian kyai dalam memumbuhkan minat bakat kewirausahaan seoang santri di pondok merupakan membagikan keteladanan kepada santri serta dibagikan pelajaran berbasis kelapangan untuk santri. Dari penelitian tersebut dikenal kalau pesantren tidak hanya aktif dalam aktivitas pembelajaran serta penyiaran agama islam, pula aktif dalam aktivitas pemberdayaan warga, ialah lewat upaya kenaikan keahlian warga desa. Kenaikan keahlian warga spesialnya dibidang pembelajaran ialah tujuan dari didirikannya pesantren. Dalam penelitian ini penulis bertujuan menjelaskan bagaimana pesantren membangun entrepreneurship santri melalui pendidikan yang ditinjau dari manajemen strategi human capital invesment. Yang menjadi pembeda dari penelitian sebelumnya. Dengan adanya penelitian ini diharapkan menjadi suatu model membangun entrepreneur santri pada pondok Pesantren yang menjadi output suatu penelitian. 
Bersumber pada penjelasan di atas, bila ditarik pada objek kajian dalam riset ini, pesantren Al-Mawadddah Kudus dan pesantren Raudlatun Nasyiin AshShidqiyyah Rembang merupakan pesantren yang masih aktif di masyarakat dan di anggap mampu memberdayakannya. Ialah Upaya kenaikan kesejahteraan warga yang dicoba oleh pondok pesantren tersebut dilatarbelakangi oleh keadaan perekonomian santri serta warga yang terdapat di dekat pesantren. Dalam upaya menolong santri serta warga yang mengalami permasalahan ini, pondok pesantren melaksanakan kegiatan- kegiatan semacam kenaikan mutu pembelajaran santri serta warga, dalam bidang pembelajaran agama Islam. Tidak hanya itu, pula melaksanakan aktivitas pembelajaran entrepreneurship untuk para santri lewat aktivitas kenaikan usaha.

\section{KAJIAN TEORI}

\section{Manajemen Strategi}

Menurut David dalam Nilasari (2014), manajemen strategi ialah seni serta ilmu buat merumusanya, implementasiya serta mengevaluasi keputusan lintas fungsional yang membuat organisasi sanggup menggapai tujuannya. Bersumber pada penafsiran tersebut kita bisa mengenali tentang cakupan manajemen strategi dalam penuhi tujuan industri mulai dari formulasi hingga proses penilaian. Tidak cuma satu bagian industri saja tetapi pula lintas fungsional yang berarti mencakup pegawai ataupun anggota dari bermacam tingkatan di industri ataupun organisasi. Menurut Peter F Drucker dalam Afri and Akbar (2015), manajemen strategi yakni sesuatu proses sosial yang dibangun buat memperoleh kerjasama, penyertaan, serta perlibatan ahliahli dalam organisasi ataupun industri buat menggapai arah dan tujuan organisasi atau perusahaan secara efektif. Tujuan tersebut diperlukan suatu kerjasama dan keterlibatan serta partisipasi sumber daya yang ada. Untuk mencapainya, diperlukan satu cara atau strategi jitu yang dipakai untuk mewujudkan pencapaian arah dan tujuan tersebut. Menurut Allison \& Kaye dalam Afri and Akbar (2015), manajemen strategi adalah "being strategic requires recognising the choices and committing to one set of responses instead of another". Dalam membuat strategi, perlu satu komando untuk merespon berbagai pilihan yang ada. Menurut Pearce dan Robinson Afri and Akbar (2015), manajemen strategi 
merujuk kepada kesatuan pengambilan keputusan dan aktivitas usaha yang merupakan hasil formulasi dan pelaksanaan rencana-rencana yang dibentuk untuk mencapai tujuan organisasi atau perusahaan. Dalam bukunya strategic management: formulation, implementation and control, Pearce dan Robinson menjelaskan beberapa hal penting dalam manajemen strategi yang dimulai dari pembentukan visi dan misi organisasi atau perusahaan sampai kepada penilaian keberhasilan dari penerapan strategi tersebut sebagai acuan untuk membuat keputusan baru yang berorientasi ke masa depan. Menurut Zulfickar, Machmud et al. (2020) Kewirausahaan Strategis merupakan kewirausahaan di tingkatan organisasi yang mencampurkan Kewirausahaan serta Manajemen Strategis yang pula mencerminkan 2 perihal semacam pencarian kesempatan aktivitas serta aktivitas pencarian hasil yang maksimal.

Dari sebagian definisi yang dikemukakan oleh para ahli di atas, bisa disimpulkan sebagian perihal: 1) Manajemen strategi ialah suatu keputusan serta aksi. 2) Manajemen strategi ialah hasil proses analisis area, baik kekuatan serta kelemahan internal, kesempatan eksternal serta ancaman eksternal terhadap sebagian aspek industri. 3) Manajemen strategi wajib diimplementasikan di segala lini industri serta oleh segala anggota industri dan wajib sanggup mengalokasikan sumberdaya yang terdapat secara efisien.

\section{Pendidikan kewirausahaan}

Menurut Saroni (2012), Pendidikan kewirausahaan adalah suatu program pendidikan yang mengklim aspek kewirausahaan merupakan sesuatu program pembelajaran yang dianggap aspek kewirausahaan selaku bagian berarti dalam bekal yang berkompetensi keanak didiknya. pada aspek ini, kita berharapkan anak didiknanti dapatmenempuh kehidupan baik. Pembelajaran berwirausaha ini diharapkan bisa jadi penilaian tambahan untuk anak didik terpaut dengan kedudukannya dalam kehidupan. Nilai tambah dalam kehidupan ialah aspek berarti karena dalam tiap aktivitas hidup kita dihadapkan pada tugas serta tanggung jawab. Tiap tugas serta tanggung jawab kehidupan merupakan buat menuntaskan kasus yang berkembang serta tumbuh dalam kehidupan. Bagi Ismatullah (2014) anak didik diwajibkan mempunyai bekal keahlian serta 
pula butuh mempunyai bekal pengetahuan serta keahlian, ada pula bekal pengetahuan yang wajib dipunyai ialah, (1) perbekalan pengetahuan menimpa usaha yang hendak merambah/ dirintis serta area usaha yang terdapat. (2) perbekalan pengetahuan tentang kedudukan serta tanggung jawab (3) perbekalan pengetahuan tentang manajemen serta pengorganisasi baru.

Setelah itu bekal keahlian yang wajib di miliki wirausaha merupakan selaku berikut:

a. Bekal keahlian terkonseptual dalam mengendalikan strategi serta menghitung resiko yang ada.

b. Bekal keahlian kreatif dalam menghasilkan nilai tambah.

c. Bekal keahlian dalam mengetuai serta mengelola.

d. Bakal keahlian berbicara serta berhubungan.

e. Bakal keahlian metode usaha yang hendak dikerjakannya.

Modalitas pendidikan kewirausahaan sangat penting untuk dimiliki oleh seorang entrepreneur. UNESCO telah menetapkan empat pilar, empat landasan, empat kekuatan, empat keutamaan, dan empat keniscayaan yang mesti dilakukan oleh dunia pendidikan sebagai berikut: "(1) Learning to know; (2) Learning to do; (3) Learning to be; (4) Learning to live together; (5) Learning to be morally".

Keempat pilar pendidikan menurut UNESCO telah mendapatkan respons yang luar biasa dalam sistem pendidikan Indonesia seperti klausal "kemandirian" yang tercatat pada tujuan pendidikan secara nasional. Hal ini artinya, pendidikan sejak PAUD sampai perguruan tinggi wajib berkarakter kemandirian, bergaya hidup mandiri, dan berbudaya sejahtera. Sejak PAUD, mereka harus sudah mendapat pendidikan kemandirian hidup sesuai dengan tugas perkembangannya, kemudian SD wajib menerapkan pendekatan pendidikan yang bisa mengantarkan mereka untuk mendiri sesuai tugas perkembangannya seperti sikap jujur, berani, teguh pada pendirian, dan kreatif. Pada saat ini SMP, mereka sudah harus diantarkan pada budaya malu, yaitu malu bila masih manja, malu bila belajarnya tidak benar, malu jika menjadi siswa nakal, dan malu bila belum punya impian masa depan. Pengetahuan 
budaya prestasi atau belajar prestasi bukan hanya prestasi belajar menjadi sangat penting. (Mursidin, 2020)

\section{Santri}

Pengistilahan santri sebetulnya memiliki dua konotasi atau pengertian. Awal, merupakan santri yang bermakna orang muslim sholeh yang menganut agama islam dengan serius serta serius cermat melaksanakan perintahperintah agama islam sebagaimana yang diketahuinya, sembari mensterilkan aqidah (kepercayaan)-nya dari syirik (mempersekutukan tuhan) yang ada di daerahnya. Dalam penafsiran ini dibedakan secara kontras dengan mereka yang diucap kelompok abangan, ialah mereka yang lebih dipengaruhi oleh nilainilai budaya jawa pra- islam, spesialnya yang berasal dari mitisme hindu serta budha. Kedua, santri merupakan siswa yang belajar di pesantren. Keduanya nampak berbeda, namun jelas pula memiliki kesamaan, ialah bersama taat dalam melaksanakan syari'at Islam. (Hariadi, 2015)

Menurut Antropolog Amerika Cliffort Greetz dalam bukunya "religion of java", seperti dijelaskan oleh Ziemek, pengertian santri ini berasal dari bahasa "sansekerta shastri" yang dalam pemakaian bahasa modern memiliki arti yang "sempit serta luas", "arti yang sempit ialah seorang pelajar sekolah agama yang disebut pesantren, dalam arti yang luas dan lebih umum kata santri mengacu pada seorang anggota bagian penduduk jawa yang menganut islam dengan sungguh-sungguh". Adapun menurut Abdurrahman Wahid, santri ialah peserta didik yang bertempat di pesantren untuk berserah diri. Santri yang dimaksudkan dalam konteks ini adalah seperti yang dikemukakan oleh Geertz dalam arti sempit, dan sebagaimana dikemukakan oleh Gus Dur.

Santri pada dunia pondok pesantren biasanya dikategorikan jadi 2 macam, ialah:

a. Santri mukim, ialah santri-santri yang berasal dari desa-desa jauh serta bertingal tetap dipesantren.

b. Santri kalong, ialah santri-santri yang berasal dari desa-desa sekitar pesantren yang umumnya tidak tidak bertampat tinggal di pesantren buat menjajaki pelajarannya di pesantren, mereka selalu pulang dari rumahnya. 
Santri merupakan santri pesantren, ia bertampat di dalam pondok, berteman serta hidup di dasar tutorial kiai serta ustad di pesantren, ia belajar keilmuan agama lewat pengraian dari kitab salaf "Kuning", mereka pula belajar ilmu universal di sekolah/madrasah ataupun di sekolah yang terdapat di dalam pesantren. Para santri hidup simpel, silih membantu dengan sesama temannya, serta silih mencurahkan isi hati serta perasaan yang mereka natural kepada sesama temannya, sedemikian rupa tercipta jalinan pengemosian yang sangat kokoh di antara mereka serta pula si kiainya. ( Junaedi, 2017)

\section{Pondok Pesantren}

Menurut Menurut Abdurrahman wahid dalam bukunya Hasan Basri pesantren merupakan suatu lingkungan dengan posisi biasanya terpisah dari kehidupan sekitarnya dimana lingkungan tersebut berdiri bangunan rumah kediaman penjaga, suatu surau ataupun masjid tempat pengajaran diberikan serta asrama tempat tinggal para santri. (Husna Nashihin, 2017)

Pesantren pada sisi estimologi berasal dari akar kata "santri" yang menemukan awalan pe- serta akhiran an- sehingga jadi "pe- santeria- an" yang bermakna kata shastri yang maksudnya murid. Pesantren berasal dari kata "shastri" yang dalam bahasa india berarti "orang-orang yang ketahui buku-buku suci" agama hindu ataupun seseorang sarjana pakar kitab-kitab suci agama hindu. Kata "shastri" berasal dari kata "shastra" yang berarti buku- buku suci, buku- buku suci agama ataupun buku- buku tentang ilmu pengetahuan. Dari penafsiran tersebut berarti pondok serta pesantren jelas ialah 2 kata yang identik ( mempunyai kesamaan makna), ialah asrama tempat santri ataupun tempat murid/ santri mengaji. (Rosyid, Subakti et al., 2020)

\section{METODOLOGI PENELITIAN}

Jenis penelitian yang dipakai dalam penelitian ini ialah penelitian studi kasus dengan rancangan multisitus. Penelitian ini mamakai pendekatan deskriptif kualitatif. Supriyadi, (2014) Menjelaskan penelitian kualitatif ialah dengan cara prosedur penelitian yang menghasilkan datanya secara deskriptif berupa pengucapan atau pentulisan serta berperilakuan bagi siapa yang lihat. 
Sumber data dalam penelitian adalah subyek dimana data dapat diperoleh seperti kyai, pengurus dan santri yang terlibat dalam kegiatan kewirausahaan. Untuk mempergampang mendapatkan data yang dibutuhkan, maka peneliti mengambil beberapa sumber data yaitu primer dan sekunder dengan teknik pengumpulan data melalui wawancara, observasi dan dokumentasi. Dan analisis data pada penelitian ini yaitu dengan mereduksi data, display data dan kesimpulan/verifikasi. Miles dan Huberman dalam Sugiyono (2020), mengemukakan bahwa "aktivitas dalam analisis data kualitatif dilakukan secara interaktif dan berlangsung secara terus menerus sampai tuntas, sehingga datanya sudah jenuh. Aktivitas dalam analisis data, yaitu data reduction, data display, dan conclusion drawing/verification".

\section{HASIL DAN PEMBAHASAN}

\section{Pendidikan Kewirausahaan Santri}

Manajemen pendidikan kewirausahaan pada santri Untuk menjadi seorang santripreneur, maka santri tidak boleh asal-asalan dalam menjalankan sesuatu, dan harus dengan pertimbangan yang matang, inilah yang membedakan antara santripreneur sejati dengan santripreneur asal jadi. Begitulah yang diterapkan pada pondok pesantren Al-Mawadah Kudus dan Pesantren Raudlatun Nasyiin Ash-Shidqiyyah Rembang, pesantren yang mempunyai model pendidikan islam yang berbasis entrepreneur. Pondok pesantren merupakan bagian dari lembaga pendidikan yang sudah sejak lama telah ada mulai pra kemerdekaan dan bahkan disinyalir sebagai lembaga pendidikan yang mempunyai ciri khas, keaslian di indonesia. Pesantren juga dianggap sebagai lembaga pendidikan agama islam tertua yang tidak dapat diragukan lagi perannya bagi perkembangan islam di dunia. (Sulisno dan Sari, 2019) peranan lembaga pendidikan pesantren juga diungkapkan oleh pengelola pesantren:

\footnotetext{
"Pesantren ini memang dirancang berbeda dengan pesantren-pesantren pada umumnya. Pengasuh memodel pesantren ini sebagai pesantren modern yang kegiatannya bukan hanya sekedar mengaji agama saja, akan tetapi juga banyak belajar hal mengenai kewirausahaan pada santri tanpa meninggalkan ciri khas pesantren yaitu dengan mengaji"
} 
Dari penuturan responden di atas kita dapat melihat bahwa pesantren memodel pendidikan sedemikian rupa dengan menerapkan beberapa kegiatan seperti spiritual yaitu merupakan landasan kehidupan sesorang, dengan menjalankan syari'at agama Islam manusia akan selamat dari jalan yang menjerumuskan dana akan membawa ke jalan yang benar. Kemudian leadership, yaitu pelatihan yang diberikan lembaga-lembaga atau dinas kepada para pelajar, mahasiswa dan santri sendiri. Para pengasuh mendorong para santrinya untuk menjadi sorang pemimpin yang hebat sebagaimana yang telah disuritauladani oleh baginda Nabi Muhammad SAW. Dan entreprenurship, yaitu pondok pesantren Entreprenur Al-Mawaddah mengajarkan bagaimana menjadi santripeneur yang baik dan bahkan mendorong para santri untuk menjadi pengusaha yang sukses semuda mungkin dengan mencari rezeki yang halal dan berkah serta sesuai aturan syari'at islam. Seperti Apa yang diungkapkan oleh Sulisno dan Sari, (2019) bahwa Pesantren seharusnya selalu menunjukkan perliku adaptif terhadap perubahan zaman, sehingga masyarakat tidak berpindah ke lain hati untuk meninggalkannya. Pesantren juga mempunyai berbagai harapan dan predikat yang selalu melekat pada dirinya.

Pesantren juga telah membekali pendidikan kewirausahaan dan bekal agama sehingga jati diri sebagai seorang santri tidak hilang. Pendidikan kewirausahaanya ialah suatu pemprograman pendidikan yang mengklim aspek kewirausahaanya sebagai pembagian terpenting dalam pembekelan kompetensi santri. Dengan aspekini, pesantren berharap santri dapatmenjalani kehidupan dengan baik. pendidikan kewirausahaanya juga diharapakan dapat menjadi nilai tambah bagi santri terkait dengan peranannya di dunia ini. Nilai tambahan bagi santri didalam kehidupannya merupakan aspek yang sangat terpenting, disebabkan dalam setiap kegiatannya kehidupan nanti dituntutkan pada tugas serta tanggung jawab masing-masing (Saroni, 2012)

Pesantren berupaya melahirkan santri untuk bisa menumbuhkan minat berwirausaha di kalangan masyarakat ketika mereka sudah lulus dari pesantren melalui pendidikan kewirausahaan yang terstruktur, adapaun yang dilakukan pesantren dengan 3 tahapan sebagai berikut: 


\section{a. Rekrutmen,}

Proses Rekrutmen Santri Dilakukan Dengan Persyaratan Sebagi Berikut:

1. santri yang ingin masuk pesantren tidak boleh menerima kiriman orang tua sebagai bentuk kemandirian santri ketika di pesantren

2. santri harus datang sendirian tanpa di dampingi orang tua untuk membentuk mental santri.

\section{b. Pembekalan}

Pembekalan dilakukan dengan berbagai aspek, diantaranya adalah pemberian pendidikan kewirausahaan, pelatihan kewirausahaan dan praktik secara langsung.

\section{Materi}

Kaitannya serta materi pelatihannya di dalam manajemen kewirausahaan santri ini, seharusnya harus ada buku pedomannya. Karena memang tujuan dari pendidikan keiwirausahaan adalah menekankan pada aspek pengetahuan, pemahan dan kreatititas murid, namun dari wawancara serta pengobservasian peneliti pada saat riset dapat ditemui dalam materi-materi kewirausahaan santri baik tidak tertulis secara detail akan tetapi ada implementasi nanti. Materi kewirausahaan diantaranya sebagai berikut:
a) kewirausahaan berbasis agama
b) pengelolaan kewirausahaan
c) pengetahuan kewirausahaan
d) keterampilan kewirausahaan
e) kepemimpinan

\section{Metode,}

Untuk memudahkan suatu program kewirausahaan seharusnya santri mempunyai metode yang dapat digunakan untuk memudahkan pelaksanaan kegiatan kewirausahaan terhadap santrinya. Dalam kegiatan kewirausahaan ini metode yang dipakai ialah "model on the job 
training" dengan bentuk pengawasan pelatih atau pengasuh. Model ini bermaksud untuk melatih santri-santri pondok pesantren Al-Mawaddah Kudus dan Pesantren Raudlatun Nasyiin Ash-Shidqiyyah Rembang untuk mempelajari pekerjaan pada satuan unit usaha di pesantren serta mereka sambil mengerjakannya. Sementara pelatih dan pengasuh terjun ke lapangan sambil memberikan bimbingan dan mempraktikkan secara perlahan cara melakukan pekerjaan tersebut dengan benar. Kemudian untuk membuat santri lebih semangat lagi dalam menggeluti dunia bisnis pesantren telah berupaya membuat suatu challenge yaitu ketika santri mendapatkan pendapatan yang paling banyak akan mendapatkan reward yang diberikan kepada santrinya. Maka ini merupakan salah satu strategi santri untuk membuat santri lebih menyenangi dunia entreprenenur.

\section{Sarana dan prasarana}

Untuk mensukseskan suatu program kegiatan kewirausahaan ini pesantren wajib memiliki peralatan penunjang yang wajib lengkap untuk memudahkan santri dalam melakukan aktivitas pekerjaannya. Dalam hal ini pesantren Al-Mawaddah Kudus dan Pesantren Raudlatun Nasyiin Ash-Shidqiyyah Rembang sudah menyiapkan semua sarana dan prasarana yang dibutuhkan santri seperti unit usaha wisata edukasi, unit usaha agro industi, unit usaha training center, unist usaha tour dan travel, unit usaha toserba yang sudah disiapkan untuk praktik santri secara langsung.

\section{c. Pendampingan}

Pendampingan dilakukan oleh pengasuh, pelatih dan para pengurus pesantren sendiri dimulai dengan pelatihan sampai praktik langsung, dengan adanya interaksi dan komunikasi yang intensif antara santri dengan pengasuh diharapkan menjadi hubungan yang sinergis antara santri dan pengasuh. Jika terdapat permasalahan pada santri, maka dilakukan diskusi untuk mencari solusinya. 
Hasil penelian ini di dukung oleh teori Pendidikan dalam Taksonomi Bloom yang terdiri dari 3 jenis yang diketahui dengan domain ataupun ranah kognitif, afektif fan psikomotik. Yang diartikan ranah- ranah ini merupakan perilaku-perilaku yang memanglah diniatkan buat ditunjukkan oleh partisipan didik serta dengan cara- cara tertentu, misalnya, bagimana mereka berfikir (ranah kognitif), gimana mereka berlagak serta merasakan suatu (ranah afektif), serta bagimana berbuat( ranah psikomotorik). Awal, pada ranah kognitif ini ada tingkatan yang mulai dari cuma bertabiat pengetahuan tentang fakta-fakta hingga kepada proses intelektual yang besar ialah mengevaluasi beberapa kenyataan. Kedua. Bloom berkomentar kalau perilaku mempunyai 3 komponen ialah kognitif, afektif, konatif. Ketiga, belajar psikomotorik menekankan keahlian motorik ialah bekerja dengan benda- benda ataupun kegiatan yang membutuhkan koordinasi saraf serta otot. Buat menarangkan konsep tersebut digunakn contoh aktivitas berdialog, menulis, bermacam kegiatan pendidikan jasmani, serta program- progran keahlian. (Syifauzakia, 2021)

\section{Kemandirian Santri dan Dampak Peningkatan Ekonomi Masyarakat}

Kegiatan kewirausahan Pesantren Al Mawaddah tidak hanya menjadikan pesantren mandiri secara finansial dan memberikan kontribusi $100 \%$ bagi operasional Pesantren, namun juga berdampak pada kemandirian santri (tidak bergantung kiriman uang dari orang tua), bahkan mampu mendorong peningkatan ekonomi masyarakat.

Salah satu program yang dilakukan untuk mewujudkan transformasi sosial tersebut adalah kegiatan pertanian terpadu (integrated farming). Sistem ini bisa meningkat penilaian serta bertambahnya produk pertanianya serta menciptakan lapangan pekerjaan terbaru di pedesaan sekaligus menahan laju urbanisasi. Dirancang dengan lebih menekankan pada aspek implementasi teknologi berkelanjutan yang ramah lingkungan. Mulai kegiatan peternakan ruminansia, budidaya buah naga dan hijauan makanan ternak (HMT), budidaya tanaman pangan dan perkebunan hingga pengolahan hasil pertanian. Sebuah solusi untuk penambahan produktivitasnya lahan, konservasi lingkungan dan pengembangan kawasan lebih secara sama. 
Untuk kegiatan paska panen, Pesantren bekerjasama dengan beberapa pabrik gula, diantaranya PG. Rendeng (Kudus) dan PG. Trangkil dan PG. Pakis (Pati), PG. Madukismo (Yogyakarta) untuk hasil perkebunan Tebu. Sementara singkong/ketela dikirim ke Indofood untuk produk keripik singkong merk Q-tela. Sebagian dikembangkan menjadi tepung mocaf atau Modified Cassava Flour. Tepung mokaf diproses secara fermentasi. Hasilnya lebih putih daripada tepung tapioka, dan secara kualitas menyamai tepung terigu. Hal ini seperti apa yang dituturkan oleh pengurus pesantren:

"Bahwa Praktik kerja yang ada di pesantren ini merupakan salah satu metode pendidikan untuk membangun kemandirian santri untuk mengembangkan jiwa wirausaha mereka. Dan pendidikan praktik langsung ini juga bertujuan untuk membiasakan santri ketika mereka sudah lulus dari pondok pesantren dan juga pihak pesantren dapat membantu santri untuk mendapatkan pemasukan atau uang jajan, serta menunjang kegiatan usaha produktif di dalam pesantren"

Dari pemaparan responden di atas, santri tidak hanya di berikan pendidikan secara teoritis saja, akan tetapi juga di berikan pendidikan praktik secara langsung sehingga dapat membentuk keterampilan santri. Praktik merupakan suatu pengaplikasian ilmu yang telah didapatkan anak didik dilembaga pendidikan. Menurut Zainuddin (2005) praktik ialah strategi pembelajaran atau bentuk pembelajaran yang digunakan secara bersamasama untuk mengasah kemampuan motorik, pengetahuan dan sikap individu dengan menggunakan sarana dan prsarana yang sudah disediakan oleh lembaga pendidikan. Sedangkan menurut Fuad dan Gofur (2009) praktik merupakan sistem penerapan ilmu yang telah didapat siswa ketika sudah terjun dilapangan.

\section{Implikasi Dari Model Pendidikan Taxonomi Bloom Dalam Membangun Jiwa Kewirausahaan Santri}

Melahirkan santri berjiwa entrepreneur, dengan melahirkan santri bejiwa entrepeneur pondok pesantren berupa keras memberikan pendidikan kewirausahaan bagi santri dengan memberikan pendidikan, pelatihan, dan menyediakan sarana prasarana atau tempat bekerja di pondok pesantren untuk praktik santri dengan supaya santri dapat menjadi mandiri dengan mengembangkan keterampilannya yang telah didapatkan selama berada 
dipesantren. Sehingga ketika santri sudah lulus dari pesantren, santri dapat menciptakan lapangan pekerjaan dan bermanfaat bagi masyarakat sekitar. Oleh karena itu santri mempunyai jiwa entrepreneur sangat penting, sebagai bukti dimasyarakat bahwa santri tidak hanya sekedar belajar ilmu agama, tetapi juga bisa berwirausaha.

Melahirkan entrepreneur berjiwa santri, menjadi seorang entrepreneur tidak hanya sekedar bisa berjualan saja, tetapi juga perlukan memilikikan jiwa santri, karena dalam hal tersebut moral anak sekarang sudah banyak terjadi kemerotan karena kurang mendapatkan pendidikan yang selayaknya. Sehingga pesantren perlu mempersipakan entrepreneur yang mempunyai jiwa santri, jiwa tawadlu, wara' dan berakhlakul karimah. Pesantren ingin menjadikan seorang entrepreneur yang memiliki jiwa santri dimana para santri memiliki sikap jujur, cerdas, dapat dipercaya dan selalu menyampaikan kebaikan dalam berdagang. Memiliki pondasi ibadah yang kuat sehingga akan mengantarkan pada pengusaha yang sukses didunia sebagai bekal di akhirat.

\section{Manajemen Strategi Human Capital Dalam Pendidikan}

Dari ulasan diatas bila dilihat dari sudut pandang manajemen strategi human capital dalam pembelajaran hingga strategi dalam sesuatu pesantren ialah planing-planing yang tersusun sedemikian hal serta berikutnya pengkelolaan yang terbaik hingga bisa diperhitungkan tiap sisi dari sebagian kegiatan dalam suatu rencana yang tersusun serta bertujuan bisa membagikan donasi positif untuk pertumbuhan pesantren serta manusianya yang berkepanjangan. Ruang lingkung manajemen strategi human capital ialah melingkup pemprosesan dalam menanggulangi bermacam permasalahan pada manusia (santri) mulai dari santri masuk pesantren sampai lulus dari pesantren. Yang bisa mendukung kegiatan pesantren demi menggapai tujuan yang sudah diresmikan. Human capital merupakan pengetahuan, keahlian serta keahlian santri yang bisa digunakan buat menciptakan layanan professional dalam perihal ini ialah pada bidang pembelajaran. Human capital mencerminkan keahlian pesantren secara kolektif buat mengahasilkan sesuatu pemecahan terbaik bersumber pada pengetahuan yang dipunyai oleh para santri yang terletak didalam pesantren ini. 
Manajemen strategi "human capital" dalam sesuatu pesantren menekankan penafsiran kalau santri ialah diantara permodalan khusus dalam melaksanakan keterberhasilan pesantren sendiri untuk penilaian serta penjumlah yang tidak terhitung, yang bisa diolah dalam sesuatu proses serta pada kesimpulannya mengashilkan nilai tambah bagai para pihak yang berkepentingan semacam, santri, orang tua, pengurus pesantren, warga, dan siapapun yang mempunyai kepentingan dari suatu upaya dalam pesantren ini. Manajemen human capital dalam pembelajaran menyangkut pada penerimaan SDM secara efisien serta hal mendasar pada SDM dalam melaksanakan tugas utama, serta guna buat menuntaskan pekerjaan tiap hari di dalam sesuatu organisasi.

Table 1

Operasionaliasi Human Capital dan Kesuksesan Organisasi

\begin{tabular}{ccc}
\hline Indicator Human Invesment & $\begin{array}{c}\text { Outcomes Of Human Capital } \\
\text { Investment }\end{array}$ & $\begin{array}{c}\text { Ukuran } \\
\text { Kesuksesan }\end{array}$ \\
\hline
\end{tabular}

1. Task-related human capital

\begin{tabular}{ll}
$>$ Star-up experience & $>$ Pengetahuan \\
$>$ Berpengalaman Bekerja & $>$ Motivasi Produktivitas \\
\hline $\begin{array}{l}\text { 2. Nontask-related human } \\
\text { capital }>\text { Keterampilan }\end{array}$ & $>$ Kinerja \\
$>$ Pendidikan & $>$ Kompetensi Kesejahteraan \\
$>$ Berpengalaman Bekerja &
\end{tabular}

Operasional ataupun dasar yang dipakai buat melaksanakan dalam pengupayaan "human capital" di dalam sesuatu organisasi bisa dilihatkan dari tabel di atas. Penanda sesorang melaksanakan penginvestasi dalam permodalan manusia ialah lewat 2 aspek "task related human capital dan nontask related human capital", yang harapannya bisa mempunyai akibat baik buat diri sendiri ataupun organaisasi semacam pondok Pesantren Al- Mawaddah Kudus serta Pesantren Al-Mawaddah Kudus dan Pesantren Raudlatun 
Nasyiin Ash-Shidqiyyah Rembang buat diterapkan kepada santri- santrinya ialah guna tingkatkan pengetahuan, motivasi, keahlian serta kompetensi dalam melaksanakan pekerjaan sehingga terdapatnya perihal tersebut para santri bisa menolong organisasi buat tingkatkan kinerja, produktivitas serta kesejahteraan bersama.

Hasil penelitian ini di dukung juga teori yang dikemukakan oleh (Prasojo, Mukminin et al., 2017) berkata Strategi yang bermutu ataupun bermutu dalam proses pencapaian butuh membutuhkan desain yang rasanya pas bisa digunakan. Desain di atas menggambarkan gimana alur yang wajib dicermati serta dicoba untuk pesantren ataupun pihak lain yang hendak melakukan pemprograman yang telah direncanakan. Terdapatnya pengelolaanya yang baik dengan terbuatnya desaint hingga proses dalam mencptakan suatu nilai dari sesuatu organisasi bisa terealisasi lewat tahapan-tahapan yang pas. Pada kesimpulannya, penbutan desaint pemprograman dari strategi manajemen humanis capital buat pengembangan kewirausahaan santri hendak bermanfaat untuk segala pemangku kepentingan di dalam organisasi/ pesantren ataupun lembaga pembelajaran yang lain.

Hasil penelitian ini juga didukung oleh model yang diterapkan oleh Wahjusaputri and Siregar (2018). Model pembelajaran Kewirausahaan (Entreprenuership) Berbasis Manajemen Strategik bagi Wirausahawan Baru yang dilakukan ialah : “(1) Pembahasan kasus (2) Games (3) Latihan (4) Presentasi kemudian disimpulkan bahwa setiap hasil pembahasan partisipatif dalam kerangka konseptual". Penelitian Hayana and Wahidmurni (2019). Mengatakan bahwa "Strategi yang diterapkan Kyai dalam memberdayakan kewirausahaan santri dilakukan dengan memberikan keteladanan berwirausaha, memberikan pembelajaran lapangan, memberikan tugas di unit usaha pesantren dan memberikan motivasi gaya kepemimpinan yang diterapkan adalah perpaduan dari gaya kepemimpinan demokratis, transformatif dan kharismatik implikasinya santri memiliki jiwa enterpreneur dan enterpreneur berjiwa santri".

Oleh sebab itu, menghasilkan desain program merupakan menghasilkan sesuatu nilai dengan membangun keahlian buat membenarkan segala kegiatan 
organisasi, dalam perihal ini merupakan pelayanan jasa pembelajaran bisa berjalan serta tumbuh dengan baik, dan bisa menghasilkan sesuatu kunggulan yang kompetititf dalam berorganisasi pada kesempatan yang hendak tiba. Penciptaan nilai dari desaint pemprogram mempunyai sebagian kegiatan yang bisa dimaksud untuk membangun sesuatu skills/ keahlian pada masa mendatang, menghasilkan kecepatan dalam strategi organisasi, serta memilah untung yang lebih dari kesempatan utama buat menghasilkan keunggulan lebih beakuasi tinggi.

\section{SIMPULAN}

Dari hasil pembahasan di atas penulis mengambil benang merah bahwasannya pendidikan kewirasuahaan santri merupakan bentuk modal investasi di masa depan ketika mereka sudah lulus dari pesantren. Dengan adanya pengajaran melalui strategi-startegi yang di jalankan pesantren dari berbagai rangkaian seperti pendidikan "spiritual, leadership and entrepreneurship" dan dengan mengadakan pelatihan dan praktik secara langsung sehingga santri diharapkan dapat memahami, mengerti dan dapat mengimplemenstasikan apa yang telah diajarkan oleh pihak pesantren.

Dengan terdapatnya strategi "manajemen human capital" ini diharapkan bisa diberdayakan serta dibesarkan sedemikian halnya sehingga bentuk pengharapan terus menjadi nyata terdapatnya. Mengenai pengembangan jiwa kewirausahaan santri, hasil penelitian berperan dalam memperkaya kazanah ilmu pengetahuan, secara teoritik penelitian ini dapat memberikan pemahaman mengenai proses pembelajaran kewirausahaan melaui pendidikan, pelatihan, dan parktik kewirausahaan santri untuk diterapkan di pondok pesantren atau lembaga pendidikan lain atau bisa digunakan sebagai bahan refensi tentang proses pengembangan jiwa kewirausahaan santri. 


\section{DAFTAR PUSTAKA}

Afidah, S. (2018). Entrepreneurship kaum santri: studi pada pesantren entrepreneur Tegalrejo Magelang, UIN Walisongo.

Afri, E. and A. Akbar (2015). "Manajemen Strategi.” Yogyakarta: Deepublish.

Andriyani, Z., et al. (2018). "Membangun Jiwa Enterpreneurship Santri Melalui Pengembangan Usaha Ekonomi Kreatif." Dimas: Jurnal Pemikiran Agama untuk Pemberdayaan 18(1): 47-64.

Fuad, N., \& Ahmad, G. (2009). Integrated human resources development. Jakarta: Grasindo.

Hariadi, S. A. (2015). EVOLUSI PESANTREN; Studi Kepemimpinan Kiai Berbasis Orientasi ESQ LKIS PELANGI AKSARA.

Hayana, N. and W. Wahidmurni (2019). "Kepemimpinan Kyai Dalam Memberdayakan Kewirausahaan Santri.” Jurnal Manajemen Pendidikan Islam (J-MPI) 4(1): 1-8.

Husna Nashihin, M. P. I. (2017). Pendidikan Karakter Berbasis Budaya Pesantren, Formaci.

Ismatullah, D. (2014). Kewirausahaan Teori dan Praktik, Bandung: CV Pustaka Setia.

Junaedi, M. (2017). Paradigma Baru Filsafat Pendidikan Islam, Kencana.

Kahfi, Z. (2016). "KEMANDIRIAN EKONOMI KAUM SARUNGAN: Pengembangan Pendidikan Entrepreneur di Pondok Pesantren." Al'Adalah 19(1).

Mursidin Dan Arifin, 2020, Pendidikan Kewirausahaan (Teori Untuk Pembuktian Dan Praktik Untuk Pembuktian Teori), Jakarta: Bumi Aksara.

Nilasari, S. (2014). “Manajemen Strategi itu Gampang.” Jakarta: Dunia Cerdas.

Prasojo, L. D., et al. (2017). "Manajemen strategi human capital dalam pendidikan.” Yogyakarta: UNY Press, Edisi 1.

Rosyid, M. Z., et al. (2020). PESANTREN DAN PENGELOLAANNYA, Duta Media Publishing.

Saroni, M. (2012). "Mendidik dan melatih entrepreneur muda." Membuka kesadaran atas pentingnya kewirausahaan bagi anak didik. Jakarta: Ar-ruzz Media. 
Sarwadi Sulisno, M. P. I., \& Sari, D. M. (2019). Manajemen Pengembangan Softskill Entrepreneurship Santri. CV. Pilar Nusantara.

Sugiyono, 2020, Metode Penelitian Kuantitatif, Kualitatif Dan R\&D, Bandung: Alfabeta

Supriyadi, Edy, 2014, Spss+Amos Statistic Data Analysis Perangkat Lunak Statistik, Bogor: In Media.

Syifauzakia, M. P., Ariyanto, B., \& Aslina, Y. (2021). DASAR-DASAR PENDIDIKAN ANAK USIA DINI. Literasi Nusantara.

Takdir, M. (2018). Modernisasi Kurikulum Pesantren, IRCiSoD.

Wahjusaputri, S. and A. F. Siregar (2018). “Kewirausahaan (Entreprenuership) Berbasis Manajemen Strategik bagi Wirausaha Baru di Kecamatan Kebayoran Lama Utara, Jakarta Selatan." Proceeding of Community Development 1: 333-342.

Yasid, A. and P. Pesantren (2018). "Meuju Pendidikan Islam Transformatif." Yogyakarta: IRCiSoD.

Zainudin, M. (2005). Pedoman Pembelajaran Praktikum di Laboratorium.

Zulfickar, R., et al. (2020). "STRATEGI KEWIRAUSAHAAN TERHADAP BUSINESS PERFORMANCE DIMEDIASI KEMAMPUAN KREATIVITAS DAN INOVASI PADA USAHA GARMEN DI PASAR TRADISIONAL BANDUNG.” Edunomic: Jurnal Ilmiah Pendidikan Ekonomi Fakultas Keguruan dan Ilmu Pendidikan 8(2): 86-95. 